\title{
Differential Effects of Microenvironmentally Presented Interleukin 3 versus Soluble Growth Factor on Primitive Human Hematopoietic Cells
}

\author{
Teruhisa Otsuka, J. Dean Thacker, Connie J. Eaves, and Donna E. Hogge \\ Terry Fox Laboratory, British Columbia Cancer Agency, Department of Medicine, Pathology, and Medical Genetics, \\ University of British Columbia, Vancouver, British Columbia V5Z 1L3, Canada
}

\begin{abstract}
The effect of IL-3 on hematopoiesis in long-term culture (LTC) was studied by cocultivating normal human marrow cells with human marrow fibroblast feeders engineered to constitutively produce IL-3 and by adding soluble IL-3 to LTC according to a variety of dose-time schedules. Feeders stably producing $7 \mathbf{n g} /$ $\mathrm{ml} \mathrm{IL-3,} \mathrm{or} \mathrm{LTC} \mathrm{to} \mathrm{which} 10 \mathrm{ng} / \mathrm{ml}$ IL-3 was added daily for 5 wk, but not once or twice weekly for the same time period, increased the output of mature nonadherent cells and progenitors from LTC as compared to control cultures. At the time of the weekly half-medium change, when primitive clonogenic progenitors in the adherent layer of standard LTC are quiescent, such cells were actively cycling in cultures containing a continuous source of an adequate dose of IL-3. In LTC, where the proportion of IL-3-producing cells in the feeder layer was diluted to $10 \%$ and no IL-3 was detectable in culture medium, primitive adherent layer progenitors were, nevertheless, maintained as a population of continuously proliferating cells. Thus, the presence of IL-3 in LTC can enhance the proliferation and differentiation of very early human hematopoietic cells, but the concentration, duration of exposure, and method of IL-3 presentation are important determinants of the ultimate effects observed. (J. Clin. Invest. 1991.88:417-422.) Key words: retrovirus $\bullet$ stroma $\bullet$ progenitor $\bullet$ long-term culture $\bullet$ marrow
\end{abstract}

\section{Introduction}

The ongoing maintenance of hematopoiesis is believed to require the presence of primitive, multipotential stem cells that are capable of self-renewal as well as yielding differentiating progeny. The latter then undergo a cascade of further irreversible differentiation steps during the course of several amplifying divisions. Ultimately this leads to the production of large numbers of mature, functional blood cells. Although the mechanisms that regulate each of these processes in vivo remain to be elucidated, involvement of a number of molecules, the socalled hematopoietic growth factors, appears likely (1). Many of these growth factors were first identified by their ability to support hematopoiesis in vitro and, for some, distinct activities have since been described. However, many examples of overlapping, synergistic, and antagonistic effects have now also

Address correspondence to Dr. Donna E. Hogge, Terry Fox Laboratory, 601 West 10th Avenue, Vancouver, British Columbia V5Z 1L3, Canada.

Received for publication 26 November 1990 and in revised form 25 March 1991.

J. Clin. Invest.

(C) The American Society for Clinical Investigation, Inc.

$0021-9738 / 91 / 08 / 0417 / 06 \quad \$ 2.00$

Volume 88, August 1991, 417-422 been documented. Given the evidence for local $(2,3)$ as well as systemic (4) mechanisms influencing multiple levels of hematopoiesis, it seems likely that a variety of growth factors may have important roles to play under different circumstances in vivo. IL-3 is of interest because it can stimulate a broad spectrum of hematopoietic cell types in vitro including the most primitive human progenitors currently detectable (5-7). These activities suggest that IL-3 might play a potentially significant role in the regulation of human hematopoiesis. On the other hand, cellular sources of IL-3 appear to be normally limited to activated $T$ cells and mast cells, and the relative importance of IL-3 in the marrow microenvironment is thus unknown.

To investigate this question, we have examined the effect of providing IL-3 to human hematopoietic cells maintained in a culture system that recreates many features of hematopoiesis in vivo (8). In these long-term cultures (LTC), ${ }^{1}$ granulopoiesis can be sustained for many weeks in the absence of exogenous hematopoietic growth factor addition due to the presence of a supportive adherent stromal cell layer. These conditions support the proliferation and differentiation of a population of very primitive hematopoietic cells which then give rise to progenitor cells detectable in standard semi-solid colony assays $(9,10)$. A negative regulatory role for the stromal cells has been inferred from the demonstration that the most primitive clonogenic progenitors in the adherent layer of undisturbed, established LTC are quiescent, whereas progenitors of the same type but not contained within the adherent layer proliferate continuously $(11,12)$. The addition of mesenchymal cell activators such as IL- $1 \beta$ to LTC stimulates both the turnover of primitive adherent layer progenitors and the production of messenger RNA for granulocyte colony stimulating factor (G-CSF), granulocyte/macrophage colony stimulating factor (GM-CSF), and IL-6 in marrow stromal cells. The similarity of the kinetics of these two responses suggests a functional relationship between them $(13,14)$. Strategies for increasing G-CSF (but not GMCSF) levels in LTC either by multiple additions of soluble factor, or by the use of genetically engineered adherent feeder cells constitutively producing G-CSF, result in the continuous cycling of primitive progenitor cells in the adherent layer (15). Thus it appears that at least one of the mechanisms whereby primitive hematopoietic cells are regulated in LTC is through the activated release of G-CSF by stromal cells.

IL-3 has not been detected in LTC either by demonstration of bioactive material in culture medium or by Northern analysis of stromal cell RNA $(14,16)$. Nevertheless, T cells do persist in LTC established from human marrow and low levels of IL-3 with significant localized effects may have thus far escaped de-

1. Abbreviations used in this paper: BFU-E, burst-forming unit, erythroid; G-CSF, granulocyte colony stimulating factor; GM-CSF, granulocyte/macrophage CSF; HMF, human marrow feeders; LTC, longterm culture; neor, neomycin phosphotransferase. 
tection. Moreover, even if IL-3 plays no role in the mechanism by which long-term hematopoiesis is sustained in vitro by supportive stromal feeders, it is possible that the provision of high levels of IL-3 to primitive hematopoietic cells in LTC might improve their maintenance and proliferative activity which could be of considerable practical interest. To evaluate these possibilities we cocultured unseparated human marrow cells for five weeks with human marrow adherent cells that had been engineered by retroviral-mediated gene transfer to constitutively produce readily detectable levels of bioactive human IL-3. The hematopoietic activity in these LTCs, as assessed by the output of mature granulopoietic cells, clonogenic progenitors, and proliferation of primitive progenitors in the adherent layer, was then compared to that seen in cultures initiated on control feeders and in standard LTCs without preestablished feeders maintained with or without the addition of exogenous IL-3 to the medium using a variety of dose-time schedules. These studies show that IL-3 can enhance multilineage hematopoiesis in LTC of human cells and that microenvironmental presentation of this molecule can trigger effects not seen after the addition of soluble material.

\section{Methods}

Retroviral constructs and viral producer cell lines. The construction of a retroviral vector allowing the transfer and expression of the cDNA for human IL-3 (from Genetics Institute, Boston, MA) will be described in detail elsewhere. Briefly, a tk-promoted IL-3 cDNA fragment was inserted $3^{\prime}$ of the neomycin phosphotransferase $\left(\right.$ neo $\left.^{\top}\right)$ gene in the N2 vector (17) and the resulting N2-tk IL-3 plasmid was then transfected into the ecotropic retroviral packaging cell line, $\psi 2$ (18). Conditioned medium from these $\psi 2$ cells was used to infect the amphotropic packaging cell line, PA317 (19). This cell line has been designed to avoid the production of competent helper virus by producer cells. G418-resistant clones of PA317 cells were selected based on results of tests for IL-3 production and for neo ${ }^{\mathrm{r}}$ viral titer on NIH-3T3 cells. Cells infected by this virus have been passaged in culture for as long as several months and then tested for their ability to generate virus that will transfer the neo ${ }^{\mathrm{r}} / \mathrm{IL}-3$ genes. Growth medium harvested from such N2-IL-3-infected cells failed to generate any G418 colonies of NIH-3T3 cells or human fibroblasts in assays which were sensitive enough to detect as few as one virus per milliliter of test medium.

Growth factors. Recombinant $E$. coli-derived GM-CSF and IL-3 were gifts from Biogen, Geneva, Switzerland, and Behring, Marburg, Germany, respectively. Recombinant IL-6 was purchased from R \& D Systems, Inc., Minneapolis, MN. Recombinant G-CSF was purchased from Amersham, Oakville, Ontario, Canada. In experiments where soluble IL-3 was added to LTC to give concentrations of up to 100 $\mathrm{ng} / \mathrm{ml}$, a crude supernate was harvested from $\operatorname{COS}$ cells that had been transfected $48 \mathrm{~h}$ previously with an expression vector containing the cDNA for IL-3 (kindly provided by Dr. R. Kay, Terry Fox Laboratory, Vancouver [20]). The undiluted supernate contained $2.5 \mu \mathrm{g} / \mathrm{ml}$ of bioactive IL-3 as compared to standard recombinant IL-3 and was therefore diluted a minimum of 25 -fold into the LTC. Supernatants from transfected COS cells showed no evidence of GM-CSF or G-CSF activity. Bioactivity consistent with $\sim 25 \mathrm{pg} / \mathrm{ml} \mathrm{IL-6}$ in undiluted supernatants was detected. Since growth medium from unstimulated, standard LTC contains $\sim 1 \mathrm{ng} / \mathrm{ml}$ IL-6 (unpublished results) this level of IL-6 in COS cell supernatant is unlikely to affect the behavior of hematopoietic cells in LTC.

Growth factor bioactivity. Growth factor bioactivity was measured in growth media collected $2 \mathrm{~d}$ after a complete medium change from viral producer cells or confluent feeder layers, and in media removed from LTC at weekly intervals. The presence of bioactivity was assessed by stimulation of ${ }^{3} \mathrm{H}$-thymidine incorporation into growth factor-responsive cell lines and quantitated by comparison to recombinant growth factor standards. GM-CSF levels were measured using human
AML193 cells as targets (21). IL-3 levels were measured on MO7-E cell targets (22). The G-CSF assay used murine NFS 60 cells obtained from Dr. J. Ihle St. Jude's Children's Hospital Memphis, TN (23). IL-6 was measured using B9 cells (24).

When the ability of diluted N2-IL-3-infected feeders to directly stimulate MO7-E cells was tested, both the infected and uninfected control feeders were irradiated with 15 grays of $250 \mathrm{KVp}$ x rays (12) and plated in 96-well plates (Nunc, Roskilde, Denmark) at $10^{4}$ cells per well. MO7-E cells at $4 \times 10^{4}$ per well were added to these feeders and cultured for $2 \mathrm{~d}$. The cells were pulsed with $1 \mu \mathrm{Ci}$ per well of ${ }^{3} \mathrm{H}$-thymidine for the last $4 \mathrm{~h}$ of incubation. Cells were then harvested using an automatic cell harvester, and ${ }^{3} \mathrm{H}$-thymidine incorporation measured in a liquid scintillation counter as for the bioactivity assays.

Cells and cultures. All tissue culture work involving amphotropic retrovirus was performed in a level III biohazard containment facility in accordance with Canadian Medical Research Council guidelines. Most cell lines were cultured in DME medium with high glucose (4.5 $\mathrm{g} /$ liter) and $10 \%$ heat inactivated calf serum (for $\psi 2$ cells) or $10 \%$ FCS (for PA317 or NIH-3T3 cells). AML193 cells and MO7-E cells were grown in Iscove's medium with $20 \%$ FCS and $10 \%$ medium conditioned by the 5637 cell line as a source of human growth factors (25). NFS 60 cells were grown in RPMI medium with 20\% FCS and 5\% PWM-stimulated mouse spleen cell conditioned medium. B9 cells were grown in DME with $10 \%$ FCS and $100 \mathrm{pg} / \mathrm{ml} \mathrm{IL-6.}$

Leftover human marrow cells were obtained from informed and consenting individuals undergoing diagnostic marrow aspiration or marrow harvest before transplantation, after approval of the Clinical Screening Committee for Research Involving Human Subjects of the University of British Columbia. Adherent layers of primary human marrow stromal cells were established from unprocessed human marrow, infected with retroviruses, and selected in G418 (Gibco/BRL, Burlington, Ontario, Canada) as previously described $(12,15)$. LTC were initiated by seeding $2.5 \times 10^{7}$ normal unprocessed nucleated marrow cells in $8 \mathrm{ml}$ of LTC medium into tissue culture dishes with or without preestablished human marrow feeders as indicated. LTC medium is a slightly modified $\alpha$ medium with $12.5 \%$ horse serum, $12.5 \%$ FCS, $10^{-4} \mathrm{M}$ 2-mercaptoethanol, and $10^{-6} \mathrm{M}$ hydrocortisone sodium hemisuccinate (11). LTC without feeders were placed at $37^{\circ} \mathrm{C}$ for the first $3 \mathrm{~d}$ of culture. All LTC were otherwise maintained at $33^{\circ} \mathrm{C}$ with weekly half-medium changes, at which time half of the nonadherent cells were also removed. Nonadherent cells from representative cultures were cytospun onto glass slides, stained with Wright Giemsa, and examined morphologically. Adherent cells were detached and prepared as a single cell suspension for plating using trypsin (11).

When single or three sequential daily doses of recombinant IL-3 were added to 3- or 4-wk-old LTC before assessing progenitor cycling, this was done $7 \mathrm{~d}$ after the previous regular half-medium change. Each LTC then received a "mock medium change" (11) in which all of the old medium and cells were removed and then returned to the culture with or without the addition of recombinant IL-3. When soluble IL-3 was added throughout the 5-wk culture period it was simply added to the fresh medium in the weekly half-medium change or to the existing culture medium between the weekly feedings.

Colony assays for hematopoietic progenitors. Assays for clonogenic granulopoietic (CFU-GM) and erythropoietic (burst-forming unit, erythroid; BFU-E) cells were performed in a standard Iscove's mediumbased methylcellulose assay containing $3 \mathrm{U} / \mathrm{ml}$ of partially purified human urinary erythropoietin and $10 \%$ (vol/vol) agar-stimulated human leukocyte conditioned media as described previously (11). Erythroid and granulocyte/macrophage colonies achieving different sizes were scored separately $\sim 3 \mathbf{w k}$ after plating using established criteria $(11,13)$. "Primitive" BFU-E and CFU-GM are those which produce more than 8 clusters of erythroid cells and more than 500 granulocytes and macrophages, respectively. "Mature" progenitors give rise to smaller colonies (3-8 erythroid clusters for BFU-E, 20-500 cells for CFU-GM).

${ }^{3} \mathrm{H}$-Thymidine suicide assay. The cell cycle status of different classes of clonogenic cells was determined by first exposing washed cells suspended in serum-free Iscove's medium to $20 \mu \mathrm{Ci} / \mathrm{ml}$ of high specific 
activity ${ }^{3} \mathrm{H}$-thymidine for $20 \mathrm{~min}$ before plating, and then comparing the final colony counts to results obtained in parallel assays of cells treated identically except that no ${ }^{3} \mathrm{H}$-thymidine was present during the initial 20-min incubation. Procedures and reagents were the same as described in detail previously $(11,13)$.

\section{Results}

Generation of IL-3-producing feeders. Titers of recombinant retrovirus, measured by the number of G418-resistant NIH$3 \mathrm{~T} 3$ cells generated from $1 \mathrm{ml}$ of growth medium from the viral producer cells, were $>10^{6} \mathrm{CFU} / \mathrm{ml}$ for PA317 cells producing N2 IL-3 virus. Growth factor bioactivity generated by the highest titer producer cells was $20 \mathrm{ng} / \mathrm{ml}$. N2 viral producers gave comparable viral titers, but no growth factor bioactivity. Confluent primary human marrow feeders (HMF) infected with the N2 IL-3 virus released $7 \mathrm{ng} / \mathrm{ml} \mathrm{IL-3}$ into the growth medium, and cells infected with the parent $\mathrm{N} 2$ virus gave undetectable IL-3 bioactivity (Table I). Production of G-CSF, GM-CSF, and IL- 6 bioactivity (14) could not be detected. After establishment of the feeders, IL-3 production remained stable for in excess of $8 \mathrm{wk}$ in culture without G418 selection.

LTC-containing IL-3-producing feeders. N2 IL-3 virus-infected HMF were then used as adherent feeder layers in LTC of normal unprocessed marrow cells. Cultures with uninfected or N2-infected HMF served as controls. There was no difference between the cultures with N2-infected and uninfected feeders for any of the parameters measured. The total number of nonadherent cells (i.e., continuously produced mature granulocytes and macrophages) was increased two to threefold over controls in LTC with IL-3-producing feeders when these were compared after 3 or 5 wk of culture (Fig. 1), but there was no apparent difference in the morphology of these nonadherent cells. Fig. 2 shows the effect of IL-3-producing feeders on the total clonogenic progenitor content (CFU-GM and BFU-E) in the same LTC. As in standard LTC (12) the majority of all progenitors were in the adherent layer and effects of the IL-3producing feeders on the numbers of both types of progenitors in both nonadherent and adherent fractions were the same. Therefore, the data for progenitors in both fractions of the LTC were combined for the comparisons shown. After both 3 and 5 wk, a similar two to threefold increase in the total number of BFU-E and CFU-GM in LTC containing IL-3-producing feeders was seen; however, neither the size nor the morphology of the colonies they formed in secondary methylcellulose assays was changed.

Table I. Retroviral Infection of Human Marrow Fibroblasts

\begin{tabular}{lcccc}
\hline & \multicolumn{4}{c}{ Bioactivity } \\
\cline { 2 - 5 } Retroviral vector & IL-3 & G-CSF & GM-CSF & IL-6 \\
\hline & \multicolumn{4}{c}{$n g / m l$} \\
N2 & $<0.1$ & $<0.1$ & $<0.01$ & $<0.02$ \\
N2-tk IL-3 & 7 & $<0.1$ & $<0.01$ & $<0.02$ \\
Uninfected & $<0.1$ & $<0.1$ & $<0.01$ & $<0.02$ \\
& & & & \\
\hline
\end{tabular}

Primary marrow infected with retrovirus and selected in G418 (see Methods). When these cells had formed confluent feeder layers the G418 selection was removed and their growth medium tested for growth factor bioactivity. These bioactivity levels remained stable for at least 8 wk when such cells were maintained in LTC medium without G418.

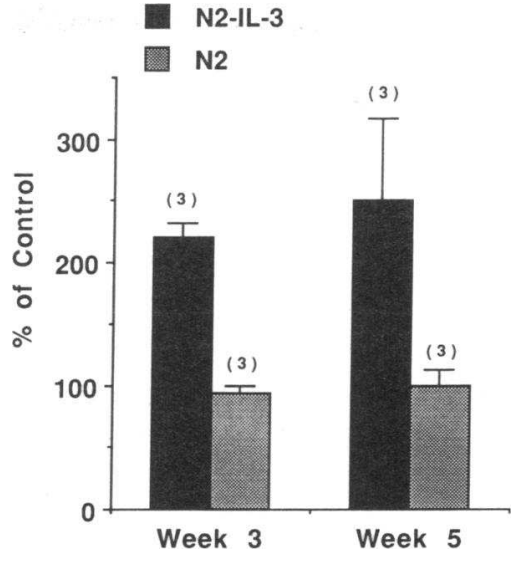

Figure 1. Nonadherent cell yields in LTC with retrovirally infected feeders. LTC containing N2-IL-3 infected HMF (solid bars) or N2 infected HMF (stippled bars) are compared with control cultures with uninfected feeders. Each bar indicates the mean of normalized values for the number of experiments indicated in brackets above the bar \pm SEM. $X \pm$ SEM absolute values for the control LTC represented as $100 \%$ on the figure were $3.8 \pm 3.0 \times 10^{6}$ and $4.3 \pm 2.6 \times 10^{6}$ nonadherent cells at 3 and $5 \mathrm{wk}$, respectively, for $2.5 \times 10^{7}$ unprocessed nucleated marrow cells initially plated.

To determine the proliferative status of the primitive progenitors in the adherent layer of these LTC, ${ }^{3} \mathrm{H}$-thymidine suicide assays were performed on cells harvested at the time of the regular weekly half-medium change. At this time primitive BFU-E and CFU-GM in the adherent layer of standard LTC are quiescent as confirmed in this study where no significant progenitor kill was seen in control LTC, nor in LTC containing N2-infected feeders. In contrast, in LTC with IL-3-producing feeders, both types of primitive progenitors were found to be actively cycling (Fig. 3).

Addition of recombinant $I L-3$ to $L T C$. To determine whether the effects seen with IL-3-producing HMF could also be achieved by adding recombinant IL-3 to LTC, standard LTC were initiated and maintained for 3 or $4 \mathrm{wk}$. At the time of the usual weekly half-medium change, some cultures received a mock medium change with addition of various concentrations of recombinant IL-3 and then, after $2 \mathrm{~d}$ further incubation, ${ }^{3} \mathrm{H}$-thymidine suicide assays were performed. Table II shows that the one-time addition of IL-3 to achieve concentrations in the medium of as high as $100 \mathrm{ng} / \mathrm{ml}$ did not stimulate

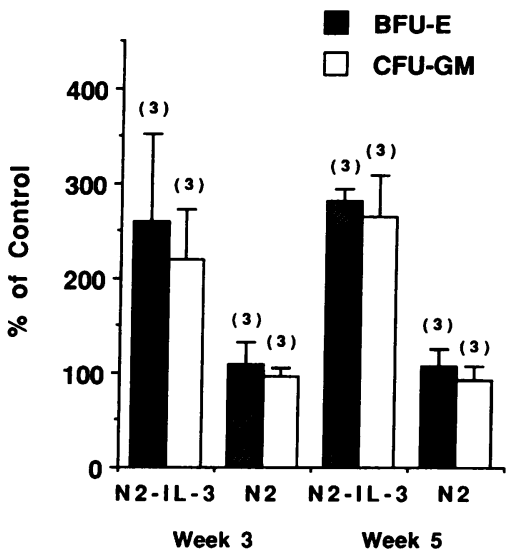

Figure 2. Progenitor content of LTC containing retrovirally infected HMF. LTC containing N2-IL-3 or N2 infected HMF are compared with cultures with normal uninfected control feeders. Each bar indicates the mean of normalized values for the number of experiments indicated in brackets above the bar \pm SEM. Progenitor content includes both adherent and nonadherent layer cell populations combined. Results for BFU-E and CFUGM are shown separately as indicated. $\mathrm{X} \pm \mathrm{SEM}$ absolute values for the control LTC represented as $100 \%$ on the figure were $185 \pm 40$ and $781 \pm 301$ at week 3 and $108 \pm 54$ and $239 \pm 60$ at week 5 for BFU-E and CFU-GM, respectively, for $2.5 \times 10^{7}$ unprocessed nucleated marrow cells initially plated. 


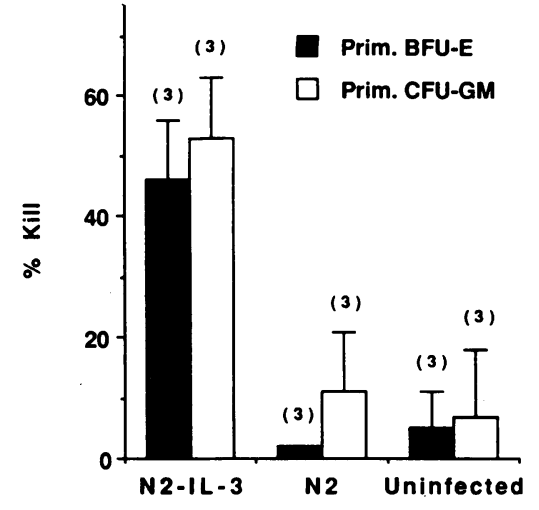

Figure 3. Proliferative status of primitive adherent layer progenitors in LTC with retrovirally infected feeders. Percen of primitive progenitors in S-phase in the adherent layer of 3 to 5-wkold LTC containing retrovirally infected HMF and parallel cultures containing normal uninfected feeders, as measured by ${ }^{3} \mathrm{H}$-thymidine suicide assays of

cells harvested $7 \mathrm{~d}$ after the previous regular half-medium change. Each bar indicates the mean percent kill of progenitors determined from the number of experiments indicated in brackets above the bar \pm SEM. Prim. BFU-E, progenitors of erythroid colonies containing $>8$ clusters; Prim. CFU-GM, progenitors of granulocyte macrophage colonies containing $>500$ cells.

the entry into S-phase of detectable numbers of primitive progenitors in the adherent layer even though $2 \mathrm{~d}$ after addition of $100 \mathrm{ng} / \mathrm{ml}$ of IL-3, at the time when the ${ }^{3} \mathrm{H}$-thymidine suicide assays were performed, IL-3 bioactivity assays indicated $15 \mathrm{ng} /$ $\mathrm{ml}$ to still be present in the culture medium. This level of IL-3 bioactivity is higher than that detected in LTC containing IL3-producing feeders where progenitor cycling was sustained. In contrast, when as little as $10 \mathrm{ng} / \mathrm{ml}$ of IL-3 was added to LTC on 3 consecutive days and cycling assays performed $2 \mathrm{~d}$ after the last growth factor addition (when the IL-3 bioactivity level in the culture medium was down to $8 \mathrm{ng} / \mathrm{ml}$ ) stimulation of the primitive progenitor cell proliferation was achieved.

To see if repeated additions of recombinant IL-3 would also affect the numbers of progenitors and mature cells recovered from LTC, growth factor was added throughout a 5-wk culture period in various schedules at a dose of $10 \mathrm{ng} / \mathrm{ml}$ (Table III) so that the total weekly dose of factor varied from 0 to $70 \mathrm{ng} / \mathrm{ml}$. IL-3 was added either once a week at the time of weekly halfmedium change, twice a week including once at the time of half-medium change as well as $4 \mathrm{~d}$ later, or daily for $5 \mathrm{wk}$.

Table II. ${ }^{3} \mathrm{H}$-Thymidine Suicide Values of Primitive Adherent Layer Progenitors in Standard LTC Following the Addition of Recombinant IL-3

\begin{tabular}{ccccc}
\hline & & \multicolumn{2}{c}{ Percent kill $(\mathrm{X} \pm$ SEM)* } & \\
Dose of IL-3 & $\begin{array}{c}\text { Frequency of } \\
\text { addition }\end{array}$ & BFU-E & CFU-GM $^{*}$ & IL-3 in LTC \\
\hline$n g / m l$ & & & & $n g / m l$ \\
None & - & $6 \pm 5$ & $7 \pm 6$ & $<0.1$ \\
10 & Once & $10 \pm 2$ & $8 \pm 8$ & 2.5 \\
100 & Once & $15 \pm 10$ & $20 \pm 8$ & 15 \\
10 & 3 days" & $41 \pm 4$ & $42 \pm 2$ & 8 \\
& & & & \\
\hline
\end{tabular}

IL-3 was added to 3 or 4-wk-old LTC beginning $7 \mathrm{~d}$ after a previous half-medium change. Cells were harvested for ${ }^{3} \mathrm{H}$-thymidine suicide assays $2 \mathrm{~d}$ after the last addition of IL- 3 and, at the same time, the culture medium was assessed for IL-3 bioactivity. ${ }^{*} \mathrm{X} \pm \mathrm{SEM}$ of three experiments. ${ }^{\ddagger}$ Primitive BFU-E ( $>8$ clusters). ${ }^{8}$ Primitive CFU-GM ( $>500$ cells). " 3 days, 3 sequential daily additions of $10 \mathrm{ng} / \mathrm{ml}$ of IL-3.
Although the single weekly dose of IL-3 was not able to sustain detectable levels of factor between feedings the twice weekly additions of $10 \mathrm{ng} / \mathrm{ml}$ maintained continuous levels of $>1-2$ $\mathrm{ng} / \mathrm{ml}$ while daily additions maintained levels $>10-15 \mathrm{ng} / \mathrm{ml}$ which is higher than those achieved by the retrovirally infected feeders $(7 \mathrm{ng} / \mathrm{ml})$. The total number of nonadherent cells increased approximately twofold in cultures given IL-3 once or twice a week, and six to eightfold in cultures given IL-3 daily. Again, in spite of such increases, there was no detectable change in the morphology of the nonadherent cells produced. There was also no change in the progenitor content of the LTC given IL-3 once or twice a week (Table III). However, both BFU-E and CFU-GM numbers did increase significantly in the LTC to which IL-3 was added daily, although neither the size nor the morphology of the colonies formed in methylcellulose assay was altered.

${ }^{3} \mathrm{H}$-thymidine suicide assays of progenitors removed from the adherent layer of these LTC at the time of their regular half-medium change showed that primitive BFU-E and CFUGM were actively cycling in cultures receiving IL-3 daily, whereas those in control cultures and in cultures receiving single or twice weekly additions of IL-3 were quiescent (Table III).

The importance of microenvironmental presentation of $I L$ 3. To examine the possibility that a hematopoietic response might be induced in LTC by feeders known to be producing IL-3 but at a level where little or no bioactivity would be detected in the culture medium, N2 IL-3 virus-infected human marrow fibroblasts were mixed in varying proportions with uninfected human marrow fibroblasts and then replated to form feeders. When the proportion of IL-3-infected feeder cells in such mixtures was $100 \%, 30 \%$, or $10 \%$, the levels of IL-3 bioactivity subsequently detected in the culture medium were $7 \mathrm{ng} / \mathrm{ml}, 1.3 \mathrm{ng} / \mathrm{ml}$, and $<0.1 \mathrm{ng} / \mathrm{ml}$, respectively. It should be noted that the two latter IL-3 concentrations are lower than those found necessary to induce cycling in adherent layer progenitors or to cause an increase in clonogenic cell numbers in the experiment where recombinant IL-3 was added throughout the 5-wk culture period (Table III). Normal marrow cells were then cocultured with the mixed control and IL-3-producing feeders (in varying combinations) and effects on progenitor numbers and cycling, and nonadherent cell output evaluated as in previous experiments (Table IV). In all three such experiments performed the numbers of nonadherent cells and total clonogenic cells did not increase significantly in cultures whose feeders contained $30 \%$ or less IL-3-producing cells. Nevertheless, in these same cultures the primitive clonogenic progenitors in the adherent layer were actively cycling, including those cultures with only $10 \%$ IL-3-producing feeders where no IL-3 bioactivity was detected in the LTC medium. The stimulating capacity of these "diluted" IL-3-producing feeders was also demonstrated when they were cocultured with the IL-3-responsive MO7-E cell line. ${ }^{3} \mathrm{H}$-thymidine incorporation into MO7-E cells grown on irradiated HMF containing 10\% IL-3producing cells was significantly (1.5 times) greater than that seen when the MO7-E cells were cocultured with the parent HMF alone.

\section{Discussion}

The localization of hematopoiesis to the bone marrow in the normal adult suggests that certain parameters critical for ongoing blood cell production must be present in this tissue. LTC 
Table III. Effects of Different Frequencies of IL-3 $(10 \mathrm{ng} / \mathrm{ml})$ Additions to LTC for Five Weeks

\begin{tabular}{|c|c|c|c|c|c|c|c|}
\hline \multirow{2}{*}{$\begin{array}{l}\text { Frequency } \\
\text { of IL-3 } \\
\text { addition }\end{array}$} & \multirow[b]{2}{*}{$\begin{array}{c}\text { No. of } \\
\text { experiments }\end{array}$} & \multirow{2}{*}{$\begin{array}{l}\text { IL-3 in LTC } \\
\text { medium at } \\
\text { week } 5\end{array}$} & \multirow[b]{2}{*}{$\begin{array}{l}\text { Nonadherent cells* } \\
\text { at week } 5\end{array}$} & \multirow[b]{2}{*}{$\begin{array}{l}\text { Total BFU-E* } \\
\text { at week } 5\end{array}$} & \multirow[b]{2}{*}{$\begin{array}{l}\text { Total CFU-GM* } \\
\text { at week } 5\end{array}$} & \multicolumn{2}{|c|}{${ }^{3} \mathrm{H}$-thymidine suicide ${ }^{\ddagger}$} \\
\hline & & & & & & BFU-E & CFU-GM \\
\hline & & $n g / m l$ & & & & & \\
\hline 0 & 3 & $<0.1$ & $100^{8}$ & $100^{8}$ & $100^{8}$ & $5 \pm 6$ & $7 \pm 11$ \\
\hline $1 / \mathrm{wk}$ & 3 & $<0.1$ & $327 \pm 30$ & $131 \pm 17$ & $121 \pm 47$ & $6 \pm 3$ & $12 \pm 10$ \\
\hline $2 / w k$ & 3 & $1-2$ & $338 \pm 17$ & $132 \pm 36$ & $118 \pm 20$ & $14 \pm 5$ & $16 \pm 3$ \\
\hline daily for $5 \mathrm{wk}$ & 2 & $10-15$ & $833 \pm 122$ & $517 \pm 273$ & $576 \pm 366$ & $50 \pm 2$ & $42 \pm 3$ \\
\hline
\end{tabular}

* Percent control, $\mathrm{X} \pm \mathrm{SEM}$ (all categories of nonadherent plus adherent progenitors combined). ${ }^{\ddagger}$ Percent kill, $\mathrm{X} \pm \mathrm{SEM}$; BFU-E (>8 clusters); CFU-GM ( $>500$ cells) from the adherent layer. ${ }^{8} \mathrm{X} \pm$ SEM absolute values for the control LTC were $1.1 \pm 0.9 \times 10^{6}, 163 \pm 107$, and $918 \pm 299$ for nonadherent cells, BFU-E, and CFU-GM, respectively, per $2.5 \times 10^{7}$ unprocessed nucleated marrow cells initially plated.

contain many of the same cell phenotypes that are found in the marrow microenvironment in vivo $(8,11,26)$ and it is now clear that these cells produce a number of hematopoietic growth factors at least transiently upon exposure to certain cytokines in vitro (14). Growth factors whose production is affected in this way include GM-CSF, G-CSF, macrophage CSF (M-CSF), and IL-6. Furthermore, cytokines that increase the production of these factors also enhance the maintenance and proliferation of hematopoietic cells in $\operatorname{LTC}(15,27)$. These data provide support for the view that one or more of these growth factors contribute to the maintenance of hematopoiesis even in complex cellular environments such as the marrow where multiple other interactions are, no doubt, occurring. Moreover, the existence of cell-cell or cell-matrix interactions may potentiate the effects of these soluble regulators $(28,29)$.

Although IL-3 has not been detected in LTC, this may reflect a lack of sensitivity in the detection methods used (14). For example, Northern analysis would not be expected to detect IL-3 mRNA if it were restricted to cells comprising $<10 \%$ of the total LTC adherent layer population. In addition, since it has been shown that IL-3 can bind to matrix proteins in bioactive form (29), IL-3 could be produced and exert an important local regulatory effect on hematopoietic cells present within the adherent layer of LTC, but still escape detection in the culture medium. Administration of IL-3 to patients has been observed to enhance hematopoiesis in vivo $(30,31)$ and a substantial, although transient, increase in hematopoietic cell output from human LTC supplemented with recombinant IL-3 has also recently been documented (27). It was therefore of interest to explore and compare the effect of microenvironmentally presented IL-3 to that seen with the addition of soluble IL-3 to human hematopoietic cells in LTC and to investigate the bio- logical basis of any stimulation observed. Our results show that the continuous presence of IL-3 for five weeks, whether presented to normal marrow cells by IL-3-producing feeders or by the daily addition of soluble factor, can lead to an increased output of both early erythroid and granulopoietic progenitors, as well as an increased output of mature granulocytes and macrophages. The proliferation of primitive adherent layer progenitors was also stimulated by either regimen. Thus, the presence of sufficient IL-3 in LTC can enhance the proliferation and differentiation of cells at multiple levels within the hematopoietic cell hierarchy.

The hematopoietic activity observed in LTC appears to represent the net effect of a variety of positive and negative regulatory influences whose relative contributions can be differentially manipulated (13). The balance achieved, and thus the nature and magnitude of the effects seen, may depend at least partly on the local concentrations of individual regulators in the vicinity of responsive cells. In the current experiments we found that a single dose of soluble IL-3 sufficient to give an initial overall concentration many times that which stimulates maximal hematopoietic colony growth in short term methylcellulose assays (27, unpublished data) was unable to induce primitive clonogenic progenitors in the adherent layer to enter S-phase. Only after multiple daily doses of recombinant IL-3 had been given to such cultures were these progenitor cells activated, i.e., the duration of exposure of the cells to IL-3 affects their response. However, there also appeared to be a dose threshold for this response since daily additions of IL-3, resulting in a continuous factor level in the LTC of at least 15 $\mathrm{ng} / \mathrm{ml}$ induced progenitor cycling and an increase in clonogenic cell numbers, whereas this effect could not be demonstrated when lower levels of between 1 and $2 \mathrm{ng} / \mathrm{ml}$ of IL- 3 were

Table IV. Effect of Feeders Containing Variable Proportions of IL-3-Producing Cells on Hematopoiesis in LTC

\begin{tabular}{|c|c|c|c|c|c|c|}
\hline \multirow{2}{*}{$\begin{array}{l}\text { Proportions } \\
\text { of IL-3-producing } \\
\text { cells in the feeder }\end{array}$} & \multirow{2}{*}{$\begin{array}{l}\text { IL-3 in } \\
\text { LTC medium } \\
\text { at week } 5\end{array}$} & \multirow[b]{2}{*}{$\begin{array}{l}\text { Nonadherent cells* } \\
\text { at week } 5\end{array}$} & \multirow[b]{2}{*}{$\begin{array}{l}\text { Total BFU-E* } \\
\text { at week } 5\end{array}$} & \multirow[b]{2}{*}{$\begin{array}{l}\text { Total CFU-GM* } \\
\text { at week } 5\end{array}$} & \multicolumn{2}{|c|}{${ }^{3} \mathrm{H}$-thymidine ${ }^{\ddagger}$ suicide } \\
\hline & & & & & BFU-E & CFU-GM \\
\hline$\%$ & $n g / m l$ & & & & & \\
\hline Uninfected & $<0.1$ & 100 & 100 & 100 & $4 \pm 8$ & $6 \pm 7$ \\
\hline 10 & $<0.1$ & $134 \pm 8$ & $129 \pm 12$ & $130 \pm 5$ & $40 \pm 4$ & $44 \pm 7$ \\
\hline 30 & 1.4 & $186 \pm 9$ & $174 \pm 25$ & $171 \pm 25$ & $46 \pm 8$ & $47 \pm 1$ \\
\hline 100 & 6.8 & $244 \pm 9$ & $228 \pm 36$ & $232 \pm 36$ & $55 \pm 13$ & $43 \pm 16$ \\
\hline
\end{tabular}

* Percent control, $\mathrm{X} \pm \mathrm{SEM}$ of three experiments. ${ }^{\ddagger}$ Percent kill, $\mathrm{X} \pm \mathrm{SEM}$ of three experiments; BFU-E ( $>8$ clusters); CFU-GM ( $>500$ cells). 
maintained. The magnitude of increase in nonadherent cell numbers was also significantly enhanced by the higher factor levels. Nevertheless, a much lower overall level of IL-3 in LTC was able to effectively stimulate primitive progenitor proliferation if presented by IL-3-producing cells within the adherent layer itself as shown by the effect of mixing IL-3-producing feeder cells 1:10 with control feeders. Presumably, the effective concentration of IL-3 in the vicinity of the responsive hematopoietic cells in these latter experiments was much higher than that predicted by levels of IL-3 detected in the culture medium $(<0.1 \mathrm{ng} / \mathrm{ml})$. This interpretation is supported by the demonstration of direct stimulation of IL-3 responsive MO7E cell proliferation when these cells were cocultured on the same diluted IL-3-producing feeders whose conditioned medium could not, by itself, stimulate MO7E cells in standard suspension cultures. Whether this was due solely to the achievement of a higher local concentration of IL-3 within the feeder layer or to a synergism with other molecular species also contained within the feeder layer, is not clear and requires further analysis.

In summary, we have shown that IL-3 supplementation can significantly enhance multiple levels of hematopoiesis in human marrow LTC. However, the type and magnitude of the response depends not only on the concentration of factor presented to target cells and the duration of their exposure to it, but also on whether the IL-3 is added exogenously or produced endogenously, the latter being a much more potent mode of IL-3 presentation. These data reopen the controversial issue of whether IL-3 may exert a regulatory function in normal human bone marrow physiology. Regardless of the answer to this question the results clearly indicate that appropriate provision of IL-3 can enhance the prolonged proliferation and differentiation of very early hematopoietic cells in vitro, a finding that may have major practical significance for future clinical applications.

\section{Acknowledgments}

The expert secretarial assistance of $T$. Allnutt is acknowledged.

This work was supported by grants from the Medical Research Council of Canada and the National Cancer Institute of Canada (NCIC). T. Otsuka is a Terry Fox Physician-Scientist Training Fellow of the NCIC and C. J. Eaves is a Terry Fox Cancer Research Scientist of the NCIC.

\section{References}

1. Metcalf, D. 1985. The granulocyte-macrophage colony-stimulating factors. Science (Wash. DC). 229:16-22.

2. Gidali, J., and L. G. Lajtha. 1972. Regulation of haemopoietic stem cell turnover in partially irradiated mice. Cell Tissue Kinet. 5:147-157.

3. Bernstein, S. E. 1970. Tissue transplantation as an analytic and therapeutic tool in hereditary anemias. Am. J. Surg. 119:448-451.

4. Chan, S. H., and D. Metcalf. 1973. Local and systemic control of granulocytic and macrophage progenitor cell regeneration after irradiation. Cell Tissue Kinet. 6:185-197.

5. Ihle, J. N., J. Keller, L. Henderson, F. Klein, and E. Palaszynski. 1982. Procedures for the purification of interleukin-3 to homogeneity. J. Immunol. 129:2431-2436.

6. Kannourakis, G., and G. R. Johnson. 1990. Proliferative properties of unfractionated, purified, and single cell human progenitor populations stimulated by recombinant human interleukin-3. Blood. 75:370-377.

7. Ganser, A., A. Lindemann, O. G. Ottmann, F. Herrmann, G. Schulz, R. Mertelsmann, and D. Hoelzer. 1989. Effect of recombinant human interleukin-3 in vivo-a phase I trial. Exp. Hematol. (NY). 17:484. (Abstr.)

8. Eaves, A. C., J. D. Cashman, L. A. Gaboury, and C. J. Eaves. 1987. Clinical significance of long-term cultures of myeloid blood cells. CRC Crit. Rev. Oncol. Hematol. 7:125-138.
9. Sutherland, H. J., C. J. Eaves, A. C. Eaves, W. Dragowska, and P. M. Lansdorp. 1989. Characterization and partial purification of human marrow cells capable of initiating long-term hematopoiesis in vitro. Blood. 74:1563-1570.

10. Sutherland, H. J., P. M. Lansdorp, D. H. Henkelman, A. C. Eaves, and C. J. Eaves. 1990. Functional characterization of individual human hematopoietic stem cells cultured at limiting dilution on supportive marrow stromal layers. Proc. Natl. Acad. Sci. USA. 87:3584-3588.

11. Cashman, J., A. C. Eaves, and C. J. Eaves. 1985. Regulated proliferation of primitive hematopoietic progenitor cells in long-term human marrow cultures. Blood. 66:1002-1005.

12. Eaves, A. C., J. D. Cashman, L. A. Gaboury, D. K. Kalousek, and C. J. Eaves. 1986. Unregulated proliferation of primitive chronic myeloid leukemia progenitors in the presence of normal marrow adherent cells. Proc. Natl. Acad. Sci. USA. 83:5306-5310.

13. Cashman, J. D., A. C. Eaves, E. W. Raines, R. Ross, and C. J. Eaves. 1990. Mechanisms that regulate the cell cycle status of very primitive hematopoietic cells in long-term human marrow cultures. I. Stimulatory role of a variety of mesenchymal cell activators and inhibitory role of TGF- $\beta$. Blood. 75:96-101.

14. Humphries, R. K., R. J. Kay, G. J. Dougherty, L. A. Gaboury, A. C. Eaves, and C. J. Eaves. 1988. Growth factor mRNA in long-term human marrow cultures before and after addition of agents that induce cycling of primitive hemopoietic progenitors. Blood. 72(Suppl. 1):121a. (Abstr.)

15. Hogge, D. E., J. D. Cashman, R. K. Humphries, and C. J. Eaves. 1991. Differential and synergistic effects of human granulocyte-macrophage colonystimulating factor and human granulocyte colony-stimulating factor on hematopoiesis in human long-term marrow cultures. Blood. 77:493-499.

16. Eliason, J. F., B. Thorens, V. Kindler, and P. Vassalli. 1988. The roles of granulocyte-macrophage colony-stimulating factor and interleukin 3 in stromal cell-mediated hemopoiesis in vivo. Exp. Hematol. 16:307-312.

17. Eglitis, M. A., P. Kantoff, E. Gilboa, and W. F. Anderson. 1985. Gene expression in mice after high efficiency retroviral-mediated gene transfer. Science (Wash. DC). 230:1395-1398.

18. Mann, R., R. C. Mulligan, and D. Baltimore. 1983. Construction of a retrovirus packaging mutant and its use to produce helper-free defective retrovirus. Cell. 33:153-159.

19. Miller, A. D., and C. Buttimore. 1986. Redesign of retrovirus packaging cell lines to avoid recombination leading to helper virus production. $\mathrm{Mol}$. Cell. Biol. 6:2895-2902.

20. Kay, R. J., G. J. Dougherty, and R. K. Humphries. 1990. Heterogeneous modifications of the 114/A10 protein of interleukin-3-dependent cells are concentrated in a highly repetitive amino-terminal domain. J. Cell. Biochem. 265: 4962-4968.

21. Santoli, D., Y.-C. Yang, S. C. Clark, B. L. Kreider, D. Caracciolo, and G. Rovera. 1987. Synergistic and antagonistic effects of recombinant human interleukin (IL) 3, IL-1 $\alpha$, granulocyte and macrophage colony-stimulating factors (G-CSF and M-CSF) on the growth of GM-CSF-dependent leukemic cell lines. $J$. Immunol. 139:3348-3354.

22. Avanzi, G. C., P. Lista, B. Giovinazzo, R. Miniero, G. Saglio, G. Benetton, R. Coda, G. Cattoretti, and L. Pegoraro. 1988. Selective growth response to IL-3 of a human leukaemic cell line with megakaryoblastic features. Br. J. Haematol. 69:359-366.

23. Weinstein, Y., J. N. Ihle, S. Lavu, and E. P. Reddy. 1986. Truncation of the c-myb gene by a retroviral integration in an interleukin 3-dependent myeloid leukemia cell line. Proc. Natl. Acad. Sci. USA. 83:5010-5014.

24. Lansdorp, P. M., L. A. Aarden, J. Calafat, and W. P. Zeiljemaker. 1986. A growth-factor dependent B-cell hybridoma. In Current Topics in Microbiology and Immunology. M. Potter and F. Melchers, editors. Springer-Verlag, Berlin, Heidelberg. 105-113.

25. Welte, K., E. Platzer, L. Lu, J. L. Gabrilove, E. Levi, R. Mertelsmann, and M. A. S. Moore. 1985. Purification and biochemical characterization of human pluripotent hematopoietic colony-stimulating factor. Proc. Natl. Acad. Sci. USA. 82:1526-1530.

26. Dexter, T. M., E. Spooncer, D. Toksoz, and L. G. Lajtha. 1980. The role of cells and their products in the regulation of in vitro stem cell proliferation and granulocyte development. J. Supramol. Struct. 13:513-524.

27. Coutinho, L. H., A. Will, J. Radford, R. Schiro, N. G. Testa, and T. M. Dexter. 1990. Effects of recombinant human granulocyte colony-stimulating factor (CSF), human granulocyte macrophage-CSF, and gibbon interleukin-3 on hematopoiesis in human long-term bone marrow culture. Blood. 75:2118-2129.

28. Gordon, M. Y., G. P. Riley, S. M. Watt, and M. F. Greaves. 1987. Compartmentalization of a haematopoietic growth factor (GM-CSF) by glycosaminoglycans in the bone marrow microenvironment. Nature (Lond.). 326:403-405.

29. Roberts, R., J. Gallagher, E. Spooncer, T. D. Allen, F. Bloomfield, and T. M. Dexter. 1988. Heparan sulphate bound growth factors: a mechanism for stromal cell mediated haemopoiesis. Nature (Lond.). 332:376-378.

30. Ottmann, O. G., A. Ganser, G. Seipelt, M. Eder, G. Schulz, and D. Hoelzer. 1990. Effects of recombinant human interleukin-3 on human hematopoietic progenitor and precursor cells in vivo. Blood. 76:1494-1502.

31. Ganser, A., A. Lindemann, G. Seipelt, O. G. Ottmann, M. Eder, S. Falk, F. Herrmann, J. P. Kaltwasser, P. Meusers, M. Klausmann, et al. 1990. Effects of recombinant human interleukin-3 in aplastic anemia. Blood. 76:1287-1292. 